\title{
Formal Gold to Gold Transmetalation of an Alkynyl Group Mediated by Palladium: A Bisalkynyl Gold Complex as a Ligand to Palladium
}

\author{
Alberto Toledo, Isabel Meana, and Ana C. Albéniz *[a]
}

\begin{abstract}
The reaction of $[\mathrm{Au}(\mathrm{C} \equiv \mathrm{CnBu})]_{n}$ with $\left[\mathrm{Pd}\left(\eta^{3}\right.\right.$-allyl) $\left.\mathrm{Cl}\left(\mathrm{PPh}_{3}\right)\right]$ results in a ligand and alkynyl rearrangement, and leads to the heterometallic complex $\left[\mathrm{Pd}\left(\eta^{3} \text {-allyl }\right)\left\{\mathrm{Au}(\mathrm{C} \equiv \mathrm{CnBu})_{2}\right\}\right]_{2}$ (3) with an unprecedented bridging bisalkynyl gold ligand coordinated to palladium. This is a formal gold to gold transmetalation that occurs through reversible alkynyl transmetalations between gold and palladium.
\end{abstract}

The exchange of organic groups between metals is at the core of many organometallic synthetic procedures and is a key step in catalytic C-C coupling reactions. Recently, the use of two transition metal complexes in catalytic reactions, the so called bimetallic catalysis, is opening new avenues for the synthesis of molecules. ${ }^{[1-4]}$ These processes rely on the efficient exchange of organic fragments between metal co-catalysts along with a fast and efficient final coupling step that drives the reaction to completion. Among the first examples, the coupling of alkynyl groups has used the cooperative role of two metals, generally a group 11 metal and palladium as, for example, in the Sonogashira reaction. ${ }^{[5-7]}$ The transmetalation of an alkynyl group between palladium and copper, or palladium and silver is a reversible reaction and this has been shown experimentally. ${ }^{[8,9]}$ After the transfer of the alkynyl group to palladium, the group 11 metal may remain coordinated to the Pd-alkynyl groups forming stable bimetallic intermediates. ${ }^{[9]}$ Both features are important since they influence the formation of the $\left[\mathrm{Pd}\left(\right.\right.$ alkynyl) $\left.R L_{2}\right]$ intermediate that eventually give, by reductive elimination, the coupling alkynyl-R derivative. We have previously studied the transmetalation reaction between copper or silver alkynyls and palladium allylic derivatives. The reluctance of the allylic fragment to undergo reductive elimination in a $\left[\mathrm{Pd}(\right.$ alkynyl $)($ allyl $\left.) L_{2}\right]$ compound hampers the otherwise preferred coupling process and allows the detection of bimetallic intermediate complexes. ${ }^{[9]}$ We report here the reaction of gold alkynyls with palladium allylic derivatives which turns out to be a complex process that involves multiple transmetalations between $\mathrm{Au}$ and $\mathrm{Pd}$ leading to a formal $\mathrm{Au}$ to Au alkynyl transfer. The impulse experienced by gold catalysis makes this metal an attractive candidate for the design of bimetallic catalysts, ${ }^{[2,10]}$ and this has been realized both in alkynyl coupling as in the gold cocatalyzed version of the Sonogashira reaction, ${ }^{[11]}$ or other Pd-

[a] A. Toledo, Dr. I. Meana and Prof. Dr. A. C. Albéniz IU CINQUIMA/Química Inorgánica.

Universidad de Valladolid

47071-Valladolid. Spain.

E-mail: albeniz@qi.uva.es

Supporting information for this article is available on the WWW under http://dx.doi.org/10.1002/chem.2014xxxxx.
Au catalyzed reactions. ${ }^{[12-17]}$ In this context, it is important to gather information about the transmetalation processes between gold and palladium and the possible rearrangement events that can take place.

The reaction of $\left[\mathrm{Pd}\left(\eta^{3}\right.\right.$-allyl)Cl( $\left.\left(\mathrm{PPh}_{3}\right)\right]$ (1) with a twofold molar amount of $[\mathrm{Au}(\mathrm{C} \equiv \mathrm{CnBu})]_{n}(2)$ leads to the heterometallic $\mathrm{Pd}-\mathrm{Au}$ complex 3 and [AuClPPh ${ }_{3}$ as the only byproduct (Scheme 1). Complex 3 is a zwitterionic species that shows cationic palladium allyl units coordinated to anionic bridging $\left[\mathrm{Au}(\mathrm{C} \equiv \mathrm{CnBu})_{2}\right]^{-}$fragments. The formation of $\mathbf{3}$ results from the reorganization of both the neutral ligands and the alkynyl fragments between metals. When the reaction is carried out using an equimolar amount of $\mathbf{1}$ and $\mathbf{2}$, the reaction proceeds in the same fashion but only half of the starting 1 is transformed. A different combination of reagents having the same total number of atoms can also be used, i.e. a mixture of the dimeric allylic palladium complex $\mathbf{4}$ and the gold derivatives $\mathbf{2}$ and $\mathbf{5}$ (Scheme 1).

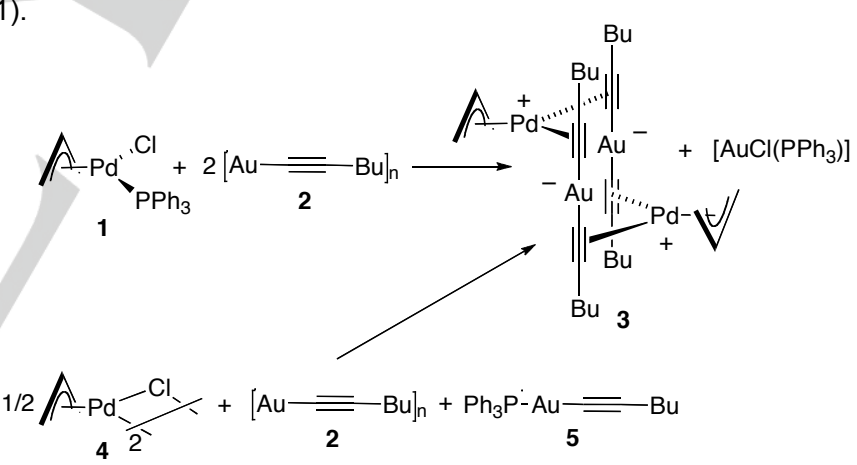

Scheme 1. Reactions leading to the formation of complex 3.

The synthetic routes depicted in Scheme 1 are not convenient for the isolation of $\mathbf{3}$ since the separation of the gold byproduct $\left[\mathrm{AuCl}\left(\mathrm{PPh}_{3}\right)\right]$ from 3 is difficult. Besides, 3 decomposes in solution with a half life of about $1 \mathrm{~h}$ at room temperature. For this reason, a different reaction route was devised that involves the use of $\left[\mathrm{Au}(\mathrm{C} \equiv \mathrm{CR})_{2}\right]^{-}$as reagent (either generated in situ for $\mathrm{R}=n \mathrm{Bu}$ or previously prepared for $\mathrm{R}=$ $\mathrm{C}_{6} \mathrm{H}_{4} \mathrm{OMe}-p$ ) and its coordination to a preformed cationic palladium allyl (Scheme 2$)$. In this way $3(\mathrm{R}=n \mathrm{Bu})$ was isolated and $6\left(\mathrm{R}=\mathrm{C}_{6} \mathrm{H}_{4} \mathrm{OMe}-p\right)$ was detected. They were characterized by NMR spectroscopy, where both the ${ }^{1} \mathrm{H}$ and ${ }^{13} \mathrm{C}$ NMR spectra are quite simple reflecting the high symmetry of the complexes. A characteristic and revealing $A B X_{2}$ system is observed for the diastereotopic methylene hydrogens of the $\mathrm{Au}-\mathrm{C} \equiv \mathrm{CCH}_{2}-\mathrm{CH}_{2}-\mathrm{Et}$ groups of complex $\mathbf{3}$ (see Supporting information). 


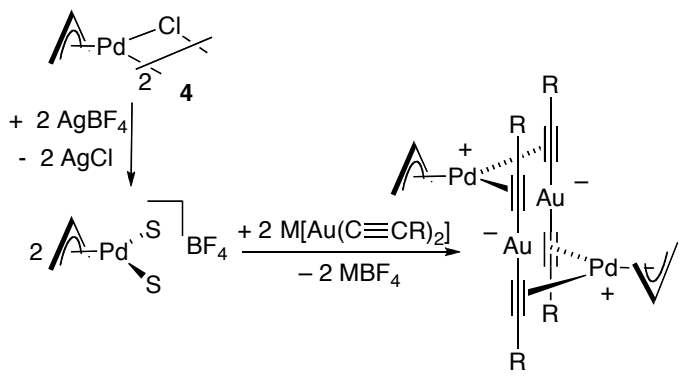

$\mathrm{R}=n-\mathrm{Bu}, \mathbf{3} ; p-\mathrm{C}_{6} \mathrm{H}_{4} \mathrm{OMe}, \mathbf{6}$

Scheme 2. Alternative synthesis of complexes $\mathbf{3}$ and $\mathbf{6}$

The molecular structure of $\mathbf{3}$, determined by X-ray crystal diffraction at $120 \mathrm{~K}$, shows a centrosymmetric derivative with two allylpalladium fragments, in a mutual trans arrangement, bridged by two $\left[\mathrm{Au}(\mathrm{C} \equiv \mathrm{CnBu})_{2}\right]^{-}$complexes (Figure 1). ${ }^{18}$ The Au$\mathrm{C}$ (alkynyl) bond lengths are in accordance with the literature data for other gold alkynyls. ${ }^{[19,20]}$ The $\mathrm{C} \equiv \mathrm{C}$ bond also conforms to the values reported in the literature and it is not very sensitive to coordination to another metal. ${ }^{19}$ The bond distances and angles of the allylic fragments as well as the $\mathrm{Pd}-\mathrm{C}$ (allyl) distances are within the range found for other palladium allyl complexes with ligands of moderate trans influence. ${ }^{[1,22]}$ The value of the Au-Au distance $(3.255(10) \AA$ ) falls in the range found for aurophilic contacts. ${ }^{[23]}$ The Au-Pd distance (3.231(10) $\AA$ ) is shorter than the sum of van der Waals radii $(3.29 \AA)$ and could indicate weak metalophilic interactions. The solid state structure is kept in solution and, besides the ${ }^{1} \mathrm{H}$ NMR pattern mentioned above, ${ }^{1} \mathrm{H}$ DOSY experiments give a hydrodynamic radius $\left(R_{H}=5.11 \AA\right.$ at $293 \mathrm{~K}$ ) that is consistent with the radius determined from the $X$ ray molecular structure $\left(R_{\text {X-ray }}=4.86 \AA\right)$.
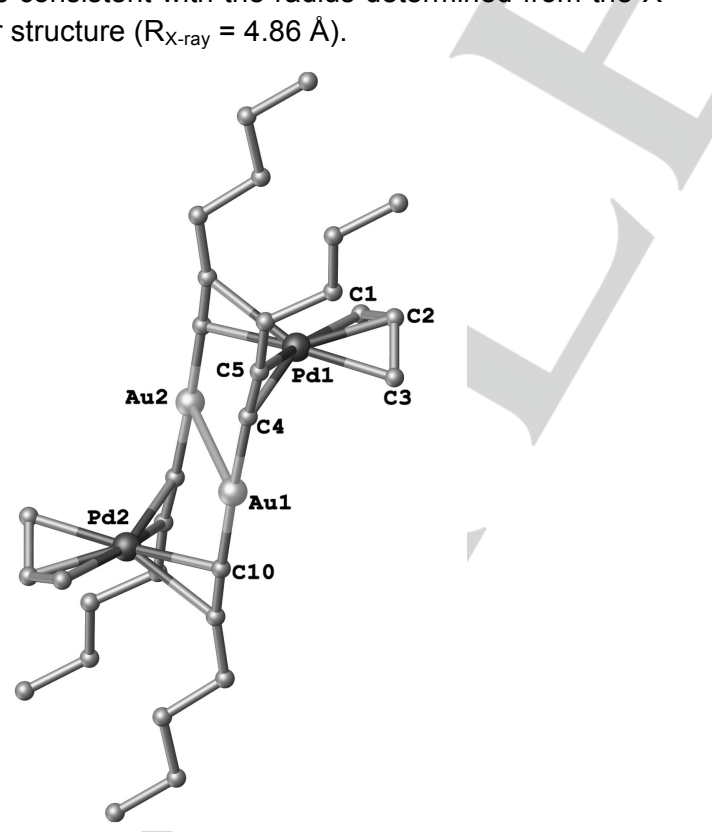
by the reaction of the allylic dimeric complex 4 and a slight excess of $\mathrm{SnBu}_{3}(\mathrm{C} \equiv \mathrm{CnBu})$ at $243 \mathrm{~K}$. Consistent with its dimeric nature 8 is a mixture of cis and trans isomers, in a 1.2:1 ratio, as a result of the two different arrangements of both allylic moieties. The addition of an excess of $[\mathrm{Au}(\mathrm{C} \equiv \mathrm{CnBu})]_{\mathrm{n}}$ to a solution of 8 at $243 \mathrm{~K}$, produces the clean formation of the bimetallic complex 3 (Scheme 4). Thus, the formation of the bisalkynyl gold species $\left[\mathrm{Au}(\mathrm{C} \equiv \mathrm{CR})_{2}\right]^{-}$occurs by transmetalation of the alkynyl moiety from palladium to gold. The reverse transmetalation, from gold to palladium, occurs by the addition of an excess of $\mathrm{PPh}_{3}$ on complex 3 , which leads to the formation of the monoalkynyl allyl palladium complex $\mathbf{9},^{[9]}$ and gold derivatives $\mathbf{5}$ and $\left[\mathrm{AuClPPh}_{3}\right.$ ] (Eq. 1)

$$
\text { (trans-8}
$$

Scheme 4. Transmetalation from Pd (8) to Au to form complex 3.

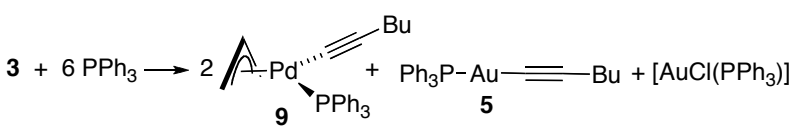

Thus, the transmetalation of the alkynyl group from gold to palladium is a reversible reaction that occurs in either direction depending on the presence of other ligands that influence the thermodynamics of the process. This has been observed before for the transmetalation of methyl and perfluorophenyl groups. ${ }^{[27]}$ In this case the solubility of $[\mathrm{Au}(\mathrm{C} \equiv \mathrm{CnBu})]_{\mathrm{n}}$ and the formation of the stable $\left[\mathrm{AuClPPh}_{3}\right]$, which takes up all the ligands coordinated to palladium, drives the equilibrium to the formation and coordination of $\left[\mathrm{Au}(\mathrm{C} \equiv \mathrm{CR})_{2}\right]^{-}$. The above mentioned experiments support the route represented in Scheme 5 for the formation of 3 by reaction of 1 and 2 in Scheme 1 .
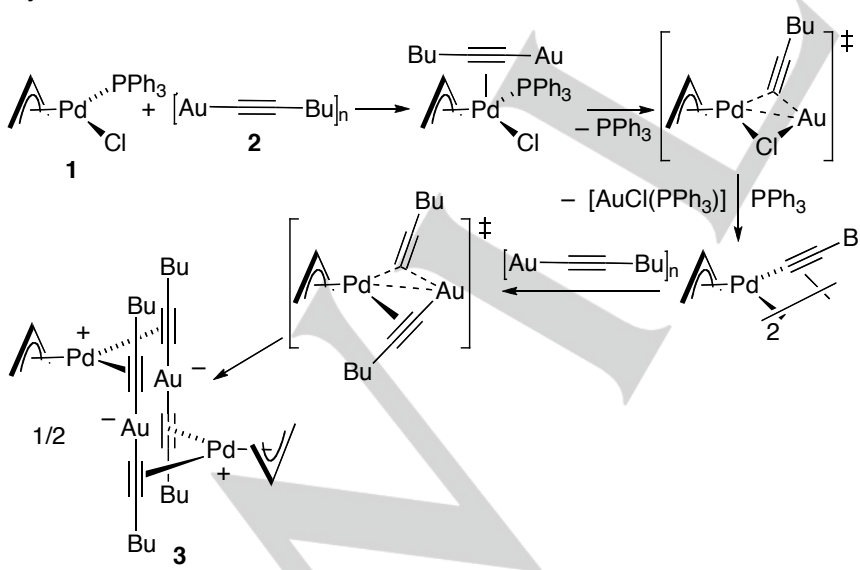

Scheme 5. Plausible route for the formation of 3.

The substitution of the $\mathrm{PPh}_{3}$ by a gold alkynyl must be the first step of the reaction. This may be an actual decoordination, as depicted in Scheme 5, or a concerted process that leads to $\mathrm{PPh}_{3}$ coordination to gold, and takes place along with the transmetalation of the alkynyl group. In any case, available coordination sites are needed either on palladium or in the gold center, so the later can trap the $\mathrm{PPh}_{3}$. The presence of $\mathrm{PPh}_{3}$ in both metal centers is detrimental for the alkynyl transfer as shown by the lack of reaction between complexes $\mathbf{1}$ and $\mathbf{5}$ in Eq. 2. On the other hand, the chloro-bridged palladium complex 4 does react with 5 to give 3 albeit in low yield since the $\mathrm{PPh}_{3}$ present inhibits further reaction (Eq. 3). It is noteworthy that no shift of the allyl ligand from an $\eta^{3}$ to a $\sigma$ coordination seems to occur. The transmetalation transition states depicted in Scheme 5 are analogous to those proposed by Espinet et al. ${ }^{[27 b]}$ and Hashmi et al. ${ }^{[28]}$ for the Au-Pd transmetalation of aryl and vinyl

$$
\begin{aligned}
& \underset{\mathbf{1}}{\text { groyps. }} \mathrm{PPh}_{\mathrm{Pd}^{\prime}}{ }^{\mathrm{Cl}}+2 \mathrm{Ph}_{3} \mathrm{P}-\mathrm{Au}=\mathrm{Bu} \underset{\mathbf{5}}{\swarrow}
\end{aligned}
$$

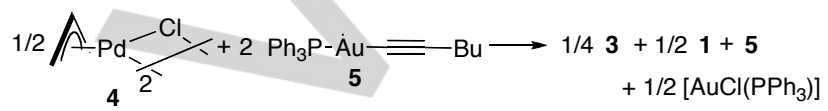

The decomposition of complex 3 leads to a mixture of the allyl-alkynyl coupling product $\mathbf{1 0}$ and the dialkyne in a 2:1 molar ratio (Eq. 4). The formation of 10 is a result of reductive elimination on a $\left[\mathrm{Pd}(\right.$ alkynyl $)($ allyl $\left.) \mathrm{L}_{2}\right]$ intermediate, so the presence of this compound shows again that the transmetalation from the bisalkynyl gold moiety to palladium takes place.

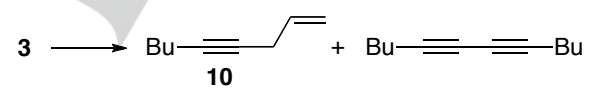

In conclusion, a formal gold to gold transfer of an alkynyl fragment occurs by sequential gold to palladium and palladium to gold transmetalations. Thus, palladium acts as a mediator in the rearrangement of the alkynyl gold complex. It is interesting to note that gold shows a distinct behaviour when compared to the other group 11 members. In the latter cases alkynyl transmetalation to palladium takes place when $[\mathrm{M}(\text { alkynyl })]_{\mathrm{n}}(\mathrm{M}=$ $\mathrm{Cu}, \mathrm{Ag}$ ) are reacted with $\mathbf{1}$, and $\mathrm{M}$ remains $\eta^{2}$-coordinated to the $\mathrm{Pd}$-alkynyl fragment leading to heterometallic complexes $\left[\left\{\mathrm{Pd}\left(\eta^{3} \text {-allyl)(alkynyl }\right) \mathrm{L}\right\} \mathrm{CuCl}\right]_{2}$ and $\left[\left\{\mathrm{Pd}\left(\eta^{3} \text {-allyl }\right)(\text { alkynyl }) L\right\}_{2} \mathrm{AgCl}\right]$ where $\sigma$-alkynyl-Pd and $\eta^{2}$-alkynyl-M coordination modes can be found. In the analogous reaction gold forms no complex of that type but acts as a ligand scavenger, forming [AuCl( $\left.\left(\mathrm{PPh}_{3}\right)\right]$, and undergo more facile transmetalation processes showing a preference for the $\sigma$-alkynyl-Au coordination mode, present in complexes $\mathbf{3}$ and $\mathbf{6}$, leaving palladium coordinated in a $\eta^{2}$ alkynyl-Pd fashion.

\section{Experimental Section}

\section{Synthesis of 3.}

Method A: A $5 \mathrm{~mm} \mathrm{NMR}$ tube was charged with $\left[\mathrm{Pd}\left(\eta^{3}-\mathrm{C}_{3} \mathrm{H}_{5}\right) \mathrm{Cl}\left(\mathrm{PPh}_{3}\right)\right]$ $(0.024 \mathrm{~g}, 0.054 \mathrm{mmol})$ and $[\mathrm{Au}(\mathrm{C} \equiv \mathrm{CnBu})]_{\mathrm{n}}(0.030 \mathrm{~g}, 0.108 \mathrm{mmol})$. Then, $\mathrm{CDCl}_{3}(0.6 \mathrm{~mL})$ was added under nitrogen at room temperature. A yellow solution was obtained and it slowly turned dark brown. After 15 minutes, 
the solution was cooled at $243 \mathrm{~K}$ and then characterized by NMR Equimolar amounts of $\mathbf{3}$ and $\left[\mathrm{AuCl}\left(\mathrm{PPh}_{3}\right)\right]^{[29]}$ were formed in solution.

Method B: A solution of $n$-butyl lithium $(0.49 \mathrm{~mL}, 1.6 \mathrm{M}$ in hexane, 0.79 $\mathrm{mmol})$ in dry THF (5 mL) was added dropwise under nitrogen to a stirred solution of 1-hexyne $(0.091 \mathrm{~mL}, 0.79 \mathrm{mmol})$ in dry THF $(5 \mathrm{~mL})$ at $-40{ }^{\circ} \mathrm{C}$. After $90 \mathrm{~min}$ at this temperature, $[\mathrm{Au}(\mathrm{C} \equiv \mathrm{CnBu})]_{\mathrm{n}}(0.22 \mathrm{~g}, 0.79 \mathrm{mmol})$ was added under nitrogen and the solution stirred at $-40{ }^{\circ} \mathrm{C}$ for 3 hours. In other Schlenk tube $\left[\mathrm{Pd}(\mu-\mathrm{Cl})\left(\eta^{3}-\mathrm{C}_{3} \mathrm{H}_{5}\right)\right]_{2}(144.5 \mathrm{mg}, 0.395 \mathrm{mmol})$ was added to a solution of $\mathrm{AgBF}_{4}(153.8 \mathrm{mg}, 0.79 \mathrm{mmol}$ ) in dry THF (5 mL). The mixture was stirred for $15 \mathrm{~min}$ protected from light and the yellow solution was removed with a syringe and added to the first solution with the preformed gold derivative at $-40{ }^{\circ} \mathrm{C}$. A light orange solution was obtained and after $30 \mathrm{~min}$ the solvent was removed in vacuum at $-20{ }^{\circ} \mathrm{C}$. The brownish residue was extracted with $\mathrm{CH}_{2} \mathrm{Cl}_{2}(3 \times 5 \mathrm{~mL})$, filtered under nitrogen and then, the filtrate evaporated to dryness. The light brown residue was triturated with dry cold hexane $(5 \mathrm{~mL})$ in a bath at -80 ${ }^{\circ} \mathrm{C}$. The resulting solid was filtered, and dried in vacuo $(227 \mathrm{mg} ; 56.7 \%$ yield). This complex was stored at $-30^{\circ} \mathrm{C} .{ }^{1} \mathrm{H} \mathrm{NMR}\left(500 \mathrm{MHz}, \delta, \mathrm{CDCl}_{3}\right.$ $243 \mathrm{~K}$ ): $5.62\left(\mathrm{~m}, 2 \mathrm{H}, \mathrm{H}^{2}\right.$ allyl), 4.12 (d, $\mathrm{J}=7.1 \mathrm{~Hz}, 4 \mathrm{H} ; \mathrm{H}_{\text {syn }}^{1} \mathrm{H}^{3}$ syn allyl), $3.41\left(\mathrm{~d}, J=12.5 \mathrm{~Hz}, 4 \mathrm{H} ; \mathrm{H}^{1}\right.$ anti, $\mathrm{H}^{3}$ anti allyl), 2.26, $2.15\left(\mathrm{ABX}_{2}\right.$ system, $J_{\mathrm{AB}}$ $\left.=16.4, J_{\mathrm{AX}}=J_{\mathrm{BX}}=7.7 \mathrm{~Hz}, 8 \mathrm{H}, \mathrm{C} \equiv \mathrm{C}-\mathrm{CH}_{2}\right), 1.48\left(\mathrm{~m}, 8 \mathrm{H} ; \mathrm{CH}_{2}-\mathrm{CH}_{2}-\mathrm{CH}_{2}\right)$, $1.33\left(\mathrm{~m}, 8 \mathrm{H} ; \mathrm{CH}_{2}-\mathrm{CH}_{3}\right), 0.83\left(\mathrm{t}, \mathrm{J}=7.3 \mathrm{~Hz}, 12 \mathrm{H} ; \mathrm{CH}_{3}\right) \cdot{ }^{13} \mathrm{C}\left\{{ }^{1} \mathrm{H}\right\} \mathrm{NMR}$

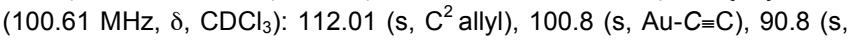
$\mathrm{Au}-\mathrm{C} \equiv \mathrm{C}), 67.1$ (s, $\mathrm{C}^{1}, \mathrm{C}^{3}$ allyl), 31.85 (s, $\left.\mathrm{CH}_{2} \mathrm{CH}_{2} \mathrm{CH}_{3}\right), 22.15$ (s, $\mathrm{CH}_{2} \mathrm{CH}_{3}$ ) $21.84\left(\mathrm{~s}, \mathrm{C} \equiv \mathrm{CCH}_{2}\right), 13.97\left(\mathrm{~s}, \mathrm{CH}_{3}\right)$. MS (ESI-TOF, dichloromethane, $\mathrm{m} / \mathrm{z}): 1037.09(\mathrm{M}+\mathrm{Na})+(\mathrm{Na}+$ comes from HCOONa used for calibration). The hydrodynamic radius determined by ${ }^{1} \mathrm{H}$ DOSY is $R_{H}=5.11 \AA(293 \mathrm{~K})$.

\section{Acknowledgements}

Financial support from the Spanish MINECO (DGI, grant CTQ2013-48406-P; fellowships to IM (FPU) and AT (FD)) and the Junta de Castilla y León (grant VA302U13) is gratefully acknowledged.

Keywords: Palladium $\bullet$ gold $\bullet$ transmetalation $\bullet$ bimetallic $•$ ligand exchange

[1] M. H. Pérez-Temprano, J. A. Casares, P. Espinet, Chem. Eur. J. 2012 18, 1864-1884

[2] J. J. Hirner, Y. Shi, S. A. Blum, Acc Chem Res. 2011, 44, 603-613.

[3] J. Park, S. Hong, Chem. Soc. Rev. 2012, 41, 6931-6943.

[4] J. A. Mata, F. E. Hahn, E. Peris, Chem. Sci. 2014, 5, 1723-1732.

[5] a) K. Sonogashira, Y. Tohda, N. Hagihara, Tetrahedron Lett. 1975, 16, 4467-4470; b) K. Sonogashira, J. Organomet. Chem. 2002, 653, 46-49.

[6] a) R. Chinchilla, C. Nájera, Chem. Rev. 2007, 107, 874-922; b) H. Doucet, J. -C. Hierso, Angew. Chem. Int. Ed. 2007, 46, 834-871; c) J. A. Marsden, M. M. Haley, in Metal-Catalyzed Cross-Coupling Reactions Vol. 1 (Eds.: F. Diederich, A. de Meijere), Wiley- VCH, Weinheim, 2004, Cap. 6, pp. 319-345; d) E. Negishi, L. Anastasia, Chem. Rev. 2003, 103, 1979-2017.

[7] a) U. Halbes-Létinois, P. Pale, S. Berger, J. Org. Chem. 2005, 70, 9185-9190; b) A. Carpita, L. Mannocci, R. Rossi, Eur. J. Org. Chem. 2005, 1859-1864; c) A. Mori, J. Kawashima, T. Shimada, M. Suguro, K Hirabayashi, Y. Nishihara, Org. Lett. 2000, 2, 2935-2937.

[8] a) K. Osakada, T. Yamamoto, Coord. Chem. Rev. 2000, 198, 379-399; b) K. Osakada, M. Hamada, T. Yamamoto, Organometallics 2000, 19, $458-468$; c) K. Osakada, R. Sakata, T. Yamamoto, Organometallics 1997, 16, 5354-5364; d) K. Osakada, R. Sakata, T. Yamamoto, J. Chem. Soc., Dalton Trans. 1997, 1265-1266.
[9] I. Meana, P. Espinet, A. C. Albéniz, Organometallics, 2014, 33, 1-7.

[10] H. A. Wegner, M. Auzias, Angew. Chem. Int. Ed. 2011, 50, 8236-8247.

[11] a) B. Panda, T. K. Sarkar, Synthesis, 2013, 45, 817-829; b) B. Panda, T. K. Sarkar, Chem. Commun. 2010, 46, 3131-3133; c) T. Lauterbach, M. Livendahl, A. Rosellón, P. Espinet, A. M. Echavarren, Org. Lett. 2010, 12, 3006-3009; d) L. A. Jones, S. Sanz, M. Laguna, Cat. Today 2007, 122, 403-406; e) A. B. Antonova, M. I. Bruce, B. G. Ellis, M. Gaudio, P. A. Humphrey, M. Jevric, G. Melino, B. K. Nicholson, G. J. Perkins, B. W. Skelton, B. Stapleton, A. H. White, N. N. Zaitseva, Chem. Commun. 2004, 960-961.

[12] Y. Shi, S. M. Peterson, W. W. Haberaecker III, S. A. Blum, J. Am. Chem. Soc. 2008, 130, 2168-2169.

[13] Y. Shi, S. D. Ramgren, S. A. Blum, Organometallics 2009, 28, 12751277.

[14] Y. Shi, E. Roth, S. D. Ramgren, S. A. Blum, J. Am. Chem. Soc. 2009, 131, 18022-18023

[15] a) J. J. Hirner, K. E. Roth, Y. Shi, S. A. Blum, Organometallics, 2012, 31, 6843-6850. b) M. Al-Amin, J. S. Johnson, S. A. Blum, Organometallics, 2014, 33, 5448-5456.

[16] a) J. delPozo, J. A. Casares, P. Espinet. Chem. Commun. 2013, 49 7246-7248; b) J. delPozo, D. Carrasco, M. H. Pérez-Temprano, M. García-Melchor, R. Álvarez, J. A. Casares, P. Espinet. Angew. Chem Int. Ed. 2013, 52, 2189-2193.

[17] A. S. K. Hashmi, C. Lothschütz, R. Döpp, M. Ackermann, J. D. B. Becker, M. Rudolph, C. Scholz, F. Rominger, Adv. Synth. Catal. 2012 354, 133-147.

[18] Crystallographic data (excluding structure factors) have been deposited with the Cambridge Crystallographic Data Center as supplementary publication no. CCDC-1063517. Copies of the data can be obtained free of charge on application to CCDC, 12 Union Road, Cambridge CB21EZ, UK (FAX: (+44) 1223-336-033; E-mail: deposit@ccdc.cam.ac.uk).

[19] Most gold alkynyls show Au-C bond lengths in the range 1.948-2.052 $\AA$ and $\mathrm{C} \equiv \mathrm{C}$ distances from 1.150 to $1.245 \AA$; these distances are similar when the $A u-C \equiv C$ fragment is $\eta^{2}$-coordinated (Au-C: 1.971-2.051 $\AA$; $\mathrm{C} \equiv \mathrm{C}: 1.167-1.275 \AA$ ). The Cambridge Structural Database, CCDC, 12 Union Road, Cambridge, CB2 1EZ, UK.

[20] a) J. Vicente, J. Gil-Rubio, N. Barquero, P. G. Jones, D. Bautista, Organometallics, 2008, 27, 646-659. b) J. Vicente, M. T. Chicote, M. M. Álvarez-Falcón, P. G. Jones. Organometallics, 2005, 24, 4666-4675. c) O. Schuster, H. Schmidbaur, Organometallics, 2005, 24, 2289-2296.

[21] a) A. C. Albéniz, P. Espinet, B. Martín-Ruiz, J. Chem. Soc. Dalton Trans. 2007, 3710-3714; b) A. C. Albéniz, P. Espinet, O. López-Cimas, B. Martín-Ruiz, Chem. Eur. J. 2005, 11, 242-252 and references therein.

[22] J. R. Berenguer, J. Forniés, E. Lalinde, F. Martínez. Organometallics 1996, 15, 4537-4546.

[23] P. Pyykko, Chem. Rev., 1997, 97, 597-636.

[24] J. R. Berenguer, E. Lalinde, M. T. Moreno, Coord. Chem. Rev. 2010, 254, 832-875.

[25] R. Buschbeck, P. J. Low, H. Lang, Coord. Chem. Rev. 2011, 255, $241-$ 272.

[26] a) I. O. Koshevoy, Y. -C. Chang, A. J. Karttunen, J. R. Shakirova, J. Jänis, M. Haukka, T. A. Pakkanen, P. -T. Chou, Chem. Eur. J., 2013 19, 5104-5112. b) I.O. Koshevoy, C. -L. Lin, A. J. Karttunen, J. Jänis, M. Haukka, S. P. Tunik, P. -T. Chou, T. A. Pakkanen, Chem. Eur. J., 2011, 17, 11456-11466. c) G. F. Manbeck, W. W. Brennessel, R. A Stockland, R. Eisenberg, J. Am. Chem. Soc. 2010, 132, 12307-12318.

[27] a) D. Carrasco, M. H. Pérez-Temprano, J. Casares, P. Espinet. Organometallics. 2014, 33, 3540-3545. b) M. H. Pérez-Temprano, J. Casares, A. R. de Lera, R. Álvarez, P. Espinet. Angew. Chem. Int. Ed. 2012, 51, 4917-4920.

[28] M. M. Hansmann, M. Pernpointner, R. Döpp, A. S. K. Hashmi. Chem Eur. J. 2013, 19, 15290-15203.

[29] P. Shina, A. K. Wilson, M. A. Omary, J. Am. Chem. Soc. 2005, 127, 12488-12489. 


\section{Entry for the Table of Contents}

\section{COMMUNICATION}
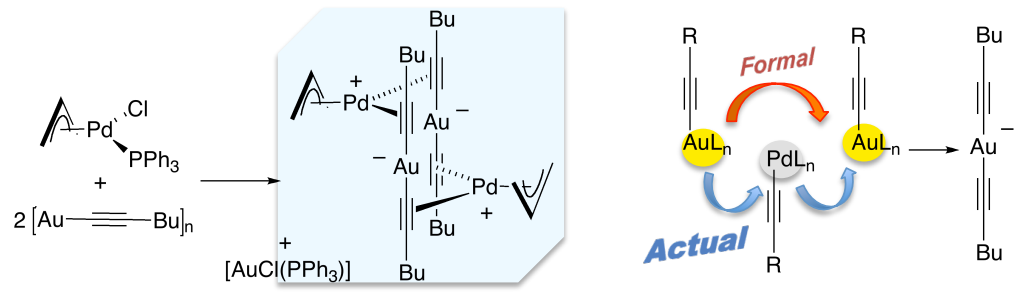

Back and forth! Direct gold to palladium and reverse palladium to gold alkynyl transmetalations effectively produce a deceptively simple gold to gold transfer. The resulting bisalkynyl gold complexes act as bridging ligands to palladium atoms in an unprecedented structure motive (see scheme).
Alberto Toledo, Isabel Meana, and Ana C. Albéniz *

Page No. - Page No.

Formal Gold to Gold Transmetalation of an Alkynyl Group Mediated by Palladium: A Bisalkynyl Gold Complex as a Ligand to Palladium 